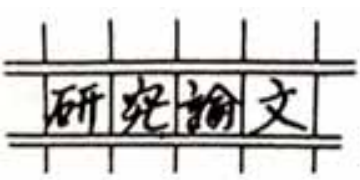

\title{
マイクロプラズマスラスターの研究開発
}

\section{Development of Microplasma Thruster}

鷹 尾 祥 典* · 斧 高 —* Yoshinori TAKAO and Kouichi ONO

(Received June 15, 2005)

\begin{abstract}
This paper proposes an electrothermal microplasma thruster using azimuthally symmetric microwave-excited plasmas, which consists of a microplasma source and a micronozzle. The microplasma source is made of a $10 \mathrm{~mm}$ long dielectric chamber of $2 \mathrm{~mm}$ in inner diameter covered with an electrically grounded metal, which produces high temperature plasmas at around atmospheric pressure. The micronozzle has a throat of $0.2 \mathrm{~mm}$ in diameter, which converts high thermal energy of plasmas into directional kinetic energy to produce the axial thrust. First, we have developed a numerical model for Ar microplasmas and micronozzle flows to estimate the thruster performance. The model consists of three modules: a volume-averaged global model, an electromagnetic model for microplasma sources, and a fluid model for micronozzle flows. Numerical results indicate that the microwave power absorbed in plasmas increases with microwave frequency $f$ and relative permittivity $\epsilon_{\mathrm{d}}$ of the dielectric chamber, to achieve the plasma density in the range $10^{14}-10^{16} \mathrm{~cm}^{-3}$. A certain combination of the frequency and permittivity significantly increases the power absorption. The micronozzle flow was found to be very lossy because of high viscosity in thick boundary layers, implying that shortening the nozzle length with increasing half-cone angles suppresses the effect of viscous loss and thus enhances the thrust performance. A thrust of $2.5-3.5 \mathrm{mN}$ and a specific impulse of 130-180 s were obtained for a given microwave power range $\left(P_{\mathrm{t}}<10 \mathrm{~W}\right)$, which is applicable to a station-keeping maneuver for microspacecraft less than $10 \mathrm{~kg}$. Moreover, we have developed a microwave-excited microplasma source, which has a dielectric chamber of $10 \mathrm{~mm}$ length and $1.5 \mathrm{~mm}$ in inner diameter, where off-the-shelf mullite $\left(\epsilon{ }_{\mathrm{d}} \approx 6\right)$ and zirconia $(\epsilon$ $\mathrm{d} \approx 12-25$ ) tubes are employed. Experiments were performed at $f=2$ and $4 \mathrm{GHz}, P_{\mathrm{t}}<10 \mathrm{~W}$, an Ar flow rate of $50 \mathrm{sccm}$, and a microplasma pressure of $10 \mathrm{kPa}$, where optical emission spectroscopy and Langmuir probe measurement were employed for the diagnostics of microplasmas. The measurements indicate that the Ar I emission intensity and plasma density $n_{\mathrm{e}}$ increase with $f$ and $\epsilon$, and that the $n_{\mathrm{e}}$ is in the range $10^{11}-10^{13} \mathrm{~cm}^{-3}$. The rotational temperature $T_{\text {rot }}$ of $\mathrm{N}_{2}$ molecule in the added gas was in the range 1100-1500 K, and the specific impulse estimated from the temperature $T=T_{\text {rot }}$ was determined to be approximately $70 \mathrm{~s}$ from the model analysis.
\end{abstract}

Key Words: Microthruster, Microplasma, Microwave, Micronozzle, Electric Propulsion

\section{1. 緒言}

近年,宇宙開発のコスト削減およびミッションのリスク軽 減を目的として 衛星の小型化に関する研究が盛んである゙1。 超小型衛星実現には各要素の小型化が不可欠であり,衛星の 軌道·姿勢制御を行う推進システムも例外ではない22)。方， プラズマの分野では今日, 樣々な応用を目指して, 直流 ${ }^{3)}$,

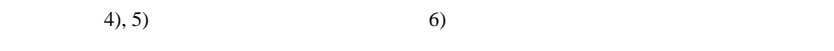
研究が精力的に行われている。本研究では, 近年, 移動体通 信用として高出力・高性能化が著しい半導体マイクロ波素子 を励起源に用いたマイクロ波励起の超小型プラズマ推進機 (マイクロプラズマスラスター) を提案し具現化をめざす。

Fig.1に, 本研究におけるマイクロプラズマスラスターの
概念図を示す。スラスターはマイクロプラズマ源とマイクロ ノズルからなる電熱加速型である。マイクロプラズマ源は半 径 $1 \mathrm{~mm}$, 長さ $10 \mathrm{~mm}$ 程度の円筒型誘電体容器と光れを覆う 金属円筒の同軸構造をなし, 容器内部の $10 \sim 100 \mathrm{kPa}$ 程度の 圧力の作動ガス に,同軸ケーブルを介してマイクロ波 $(<10$ W) を供給することでプラズマ生成に至る。マイクロノズル は, 狭まり部と広がり部を有するスロート半径 $0.1 \mathrm{~mm}$, 長 さ 1 〜 $2 \mathrm{~mm}$ 程度のラバールノズルであり, 生成された高温・ 高圧のプラズマは,マイクロノズルで空力的に超音速に加速 され推力を得る。

本稿では, まず, マイクロプラズマ源におけるプラズマの 生成・維持，およびマイクロノズルにおけるプラズマ流れに ついて , 作動ガスをアルゴンとして数值解析を行い, マイク

* 京都大学大学院工学研究科航空宇宙工学専攻 (广 606-8501 京都市左京区吉田本町)

Department of Aeronautics and Astronautics,Graduate School of Engineering, Kyoto University (Yoshida-Honmachi, Sakyo-ku, Kyoto 606-8501, Japan) 


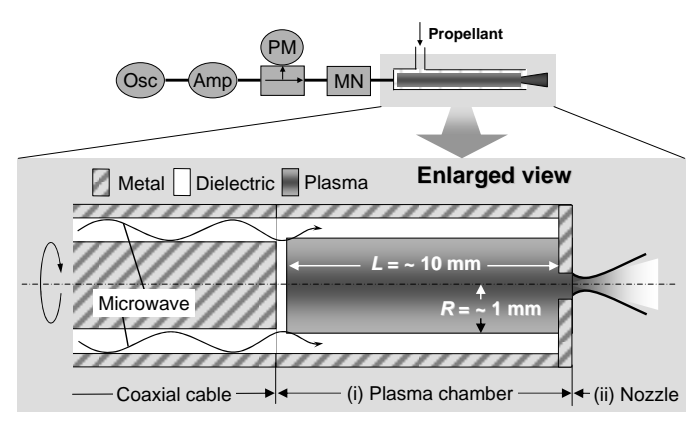

Fig.1 Schematic of microplasma thruster using microwave-excited plasmas, consisting of azimuthally symmetric microplasma source and converging-diverging (Laval) micronozzle. The working gas is $\mathrm{Ar}$ in this study. The abbreviations, Osc, Amp, PM, and MN, represent an oscillator, amplifier, power monitor, and matching network of the microwave circuits, respectively.

ロプラズマスラスターの推進性能を評価する7)-11)。さらに， マイクロプラズマ源を試作して，微小領域でのマイクロ波励 起マイクロプラズマの生成·維持, および微小オリフィスを 通しての真空中へのプラズマの超音速自由膨張を実証すると ともに,プラズマ計測・診断によりプラズマ特性を把握し， 推進特性を推算する ${ }^{8)-10) 。 ~}$

\section{2. モデル解析}

マイクロプラズマスラスターは，Fig.1 に示すように (i) マイクロプラズマ源と (ii)マイクロノズルの2つの領域に分

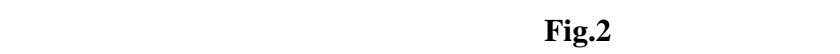
值解析を行j ${ }^{7), 8), 11 \text { 。 }}$

\section{1 モデルと基礎方程式}

モデルでは以下の仮定をする。(1)プラズマは連続体で準 中性。(2)気相反応は, 電子衝突電離とイオン - 電子 3 体衝 突再結合のみを考慮 $\left(\mathrm{Ar}+\mathrm{e} \Leftrightarrow \mathrm{Ar}^{+}+2 \mathrm{e}\right)$ 。(3)電子温度と重 粒子 (イオン , 中性粒子) 温度は異なる (2 温度モデル)。(4) プラズマ源では, 電子密度・温度等を空間一樣として取り扱 い, 電磁界は 2 次元軸対称構造をなす。(5)プラズマ源に投 入する電力は全て電子に吸収され，弾性衝突により重粒子に エネルギーか移行する。(6)ノズル流れは旋回流のない 2 次 元軸対称の層流とし，全ての粒子種の対流速度は等しい。

\subsection{1 マイクロプラズマ源}

マイクロプラズマ源は,プラズマの生成・維持に関する体積 平均グローバルモデル (Global model) ${ }^{12)}$ と, プラズマ中の マイクロ波伝播に関する電磁界モデル ${ }^{13), 14)}$ を用いて解析を 行う。グローバルモデルにより, プラズマ源に吸収されるマ イクロ波電力に対する電子密度等のプラズマパラメータを求 め, 電磁界モデルにより,プラズマ中のマイクロ波電磁界分 布を解析してプラズマでのマイクロ波吸収電力を求め, 両モ デルによる計算を収束するまで繰り返す。グローバルモデル において , 粒子バランスの式は

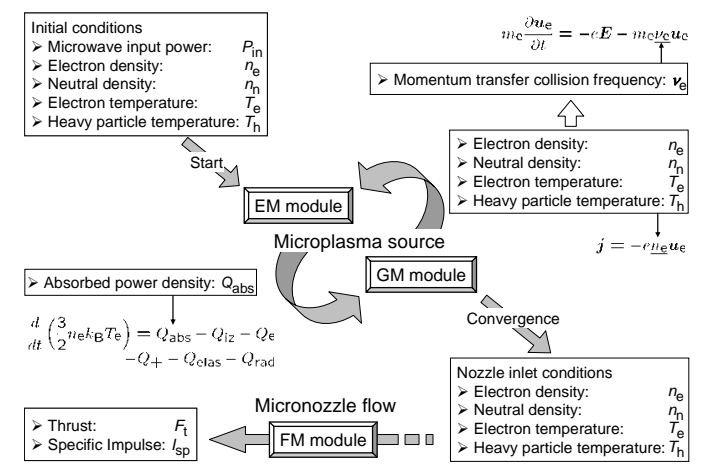

Fig.2 Schematic of numerical procedure for simulation of microplasma thruster. The model consists of three modules: Global model (GM), electromagnetic model (EM), and fluid model (FM) modules. The GM and EM modules are for microplasmas, and the FM is for micronozzle flows.

$$
\begin{aligned}
& \frac{d}{d t} n_{\mathrm{e}}=R_{\mathrm{ne}}-k_{\mathrm{d}} \\
& \frac{d}{d t} n_{\mathrm{n}}=-R_{\mathrm{ne}}+k_{\mathrm{d}} \pm S_{\mathrm{p}}
\end{aligned}
$$

また，エネルギーバランスの式は

$$
\begin{aligned}
& \frac{d}{d t}\left(\frac{3}{2} n_{\mathrm{e}} k_{\mathrm{B}} T_{\mathrm{e}}\right)=Q_{\mathrm{abs}}-Q_{\mathrm{iz}}-Q_{\mathrm{e}}-Q_{+}-Q_{\text {ela }}-Q_{\text {rad }} \\
& \frac{d}{d t}\left(\frac{3}{2} n_{\mathrm{h}} k_{\mathrm{B}} T_{\mathrm{h}}\right)=Q_{\text {ela }}-Q_{\mathrm{d}}
\end{aligned}
$$

と書ける。ここで, $n, T, k_{B}, R_{n e}, k_{d}$ は乥れ午れ粒子数密度， 温度, ボルツマン定数, 電子の生成・消滅項, および電子の 拡散損失項を表し，添字 e, n, h は光れ光れ電子，中性粒子， 重粒子 (イオン，中性粒子) を表す。また， $S_{\mathrm{p}}$ は質量流量調 節用パラメータである。さらに，Qは弚れ毞れ単位体積あた り, プラズマに吸収されるマイクロ波電力 $\left(Q_{\mathrm{abs}}\right)$, 電離・再 結合によるエネルギー輸送速度 $\left(Q_{\mathrm{iz}}\right)$, 電子の壁への拡散に よる電力損失 $\left(Q_{\mathrm{e}}\right)$ ，イオンの壁への拡散による電力損失 $\left(Q_{+}\right)$, 弾性衝突によるエネルギー輸送速度 $\left(Q_{\mathrm{ela}}\right)$, 輻射による電力 損失 $\left(Q_{\mathrm{rad}}\right)$ および重粒子の壁への拡散による電力損失 $\left(Q_{\mathrm{d}}\right)$, を表す。

一方, 電磁界モデルでは, 以下のマクスウェル方程式と電 子の運動方程式を用いる。

$$
\begin{aligned}
& \nabla \times \boldsymbol{E}=-\frac{\partial \boldsymbol{B}}{\partial t} \\
& \nabla \times \boldsymbol{B}=\mu_{0}\left(\boldsymbol{j}+\varepsilon \frac{\partial \boldsymbol{E}}{\partial t}\right) \\
& m_{\mathrm{e}} \frac{\partial \boldsymbol{u}_{\mathrm{e}}}{\partial t}=-e \boldsymbol{E}-m_{\mathrm{e}} v_{\mathrm{e}} \boldsymbol{u}_{\mathrm{e}} \\
& \boldsymbol{j}=-e n_{\mathrm{e}} \boldsymbol{u}_{\mathrm{e}}
\end{aligned}
$$

ここで, $E, B, j, u_{\mathrm{e}}$ は光れ光れマイクロ波電界, 磁界, プラ ズマ電子の電流密度,および電子流の速度を表すべクトルで ある。また , $\mu_{0}$ は真空の透磁率,$\epsilon$ は誘電率でありプラズ マ源の領域 (構成部位の材料) によって異なる。 $e, m_{\mathrm{e}}, v_{\mathrm{e}}$ は

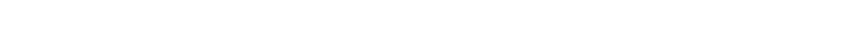
動量輸送衝突周波数である。 


\subsection{2 マイクロノズル}

マイクロノズル流れは , 2 温度モデルに基づくナヴィエ・ ストークス (Navier-Stokes) 方程式と状態方程式 ${ }^{15), 16)}$ を用い て解析を行う。

$\frac{\partial}{\partial t} \rho+\nabla \cdot(\rho v)=0$

$\frac{\partial}{\partial t}(\rho v)+\nabla \cdot(\rho v v)=-\nabla p+\nabla \tau$

$\frac{\partial}{\partial t} n_{\mathrm{e}}+\nabla \cdot\left(n_{\mathrm{e}} v\right)=\nabla \cdot\left(D_{\mathrm{a}} \nabla n_{\mathrm{e}}\right)+R_{\mathrm{ne}}$

$\frac{\partial}{\partial t}\left(\frac{3}{2} n_{\mathrm{e}} k_{\mathrm{B}} T_{\mathrm{e}}\right)+\nabla \cdot\left(\frac{5}{2} n_{\mathrm{e}} k_{\mathrm{B}} T_{\mathrm{e}} \boldsymbol{v}\right)=(\boldsymbol{v} \cdot \nabla) p_{\mathrm{e}}+\nabla \cdot \boldsymbol{q}_{\mathrm{e}}-Q_{\text {ela }}-Q_{\text {iz }}-Q_{\text {rad }}$

$\frac{\partial}{\partial t}\left(\frac{3}{2} n_{\mathrm{h}} k_{\mathrm{B}} T_{\mathrm{h}}\right)+\nabla \cdot\left(\frac{5}{2} n_{\mathrm{h}} k_{\mathrm{B}} T_{\mathrm{h}} \boldsymbol{v}\right)=(\boldsymbol{v} \cdot \nabla) p_{\mathrm{h}}+\tau: \nabla \boldsymbol{v}+\nabla \cdot \boldsymbol{q}_{\mathrm{h}}+Q_{\text {ela }}$

$p=n_{\mathrm{e}} k_{\mathrm{B}} T_{\mathrm{e}}+n_{\mathrm{h}} k_{\mathrm{B}} T_{\mathrm{h}}$

ここで, $\rho, p, v, \mathrm{~T}, q, D_{\mathrm{a}}$ は, 乥れ光れ粒子密度, 圧力, 対 流速度ベクトル, 応力テンソル, 熱流ベクトル, 両極性拡散 係数を表す。なお，本モデルにおける粘性係数などの輸送係 数は, 文献 15,16 に従った。

\section{2 数値解法}

マイクロプラズマ源の解析には,グローバルモデルに 4 次 精度 4 段階ルンゲ・クッタ法, 電磁界モデルに 2 次元軸対称 有限差分時間領域 (FDTD: Finite Difference Time Domain) 法 ${ }^{17)}$ を用いた。一方，マイクロノズル流れの解析には, 計 算格子点上に全ての物理量を定義して有限差分法を用いた。 差分はマコーマック法 ${ }^{18)}$ を適用し , 時間積分は陽解法で計 算を行った。

\section{3. モデル解析結果と考察}

\section{1 マイクロプラズマ源}

Fig.1 に示すマイクロプラズマ源に関し , プラズマが占め る範囲は半径 $1 \mathrm{~mm}$, 長さ $10 \mathrm{~mm}$, 誘電体の厚さは $0.6 \mathrm{~mm}$ とし, 同軸ケーブル部も含めて軸方向に 600 個 , 径方向に 80 個, 弚れ光れ等間隔に格子を切ってマイクロ波電磁界解 析を行う。プラズマ源の誘電体および同軸ケーブルの内部絶 縁体においては電流が流れない $(j=0)$ とし，また，式(6)中 の誘電率 $\epsilon$ を真空の誘電率 $\epsilon_{0}$ と光れ光れの比誘電率 $\epsilon_{\mathrm{d}}$ で表 $し\left(\epsilon=\epsilon_{0} \epsilon_{\mathrm{d}}\right)$ 。プラズマに吸収される電力密度を, プラズマ 体積を $V$ として,

$$
Q_{\mathrm{abs}}=\frac{1}{V} P_{\mathrm{abs}}=\frac{1}{V} \int_{V} \boldsymbol{j} \cdot \boldsymbol{E} d V
$$

より求め,この值をグローバルモデルに与えて電子密度等の プラズマパラメータを求める。電磁界モデルとグローバルモ デルを交互に繰返し解くことにより，適当な初期値の下で自 己矛盾のない解を得る。

Fig.3 に , プラズマ源の圧力が $0.1 \mathrm{MPa}$ 一定の場合におい
て, 電子密度 $n_{\mathrm{e}}$, 電子温度 $T_{\mathrm{e}}$, および重粒子温度 $T_{\mathrm{h}}$ のプラ ズマに吸収される電力密度 $Q_{\mathrm{abs}}$ に対する依存性を示す図よ り, 吸収電力の増加とともに電子密度が増加，また重粒子温 度が上昇して電子温度と熱平衡状態になって行く樣子がわか る。Fig.4に，マイクロ波周波数 $f=24.5 \mathrm{GHz}$, 誘電体の比誘 電率 $\epsilon_{\mathrm{d}}=10$ 吸収電力密度 $Q_{\mathrm{abs}}=2.0 \times 10^{7} \mathrm{~W} / \mathrm{m}^{3}\left(P_{\mathrm{abs}}=0.6 \mathrm{~W}\right)$ における , プラズマ中のマイクロ波の軸方向電界 $E_{\mathrm{z}}$ の空間 分布を示す。図より, 波の振幅か誘電体とプラズマの境界か ら径方向に指数関数的に減衰し，いわゆる表面波 (surface waves) が生じて伝播している樣子がわかる。ここで, Fig.1 に示すプラズマ領域は Fig.4 において $L=2 \sim 12 \times 10^{-3} \mathrm{~m}$ の範 囲に対応し 軸方向の原点は同軸ケーブル内部に取っている。 Fig.5 に ,プラズマ源へのマイクロ波投入電力を $P_{\text {in }}=10 \mathrm{~W}$ と して, プラズマに吸収される電力 $P_{\mathrm{abs}}$ のマイクロ波周波数 $f$ およひ誘電体比誘電率 $\epsilon_{\mathrm{d}}$ への依存性を示す。図より，周波 数および比誘電率が高いほど ,プラズマ生成が効率的である ことがわかる (プラズマ源の構造に起因するマイクロ波電力 のマッチングに関連して, 周波数, 比誘電率に対する依

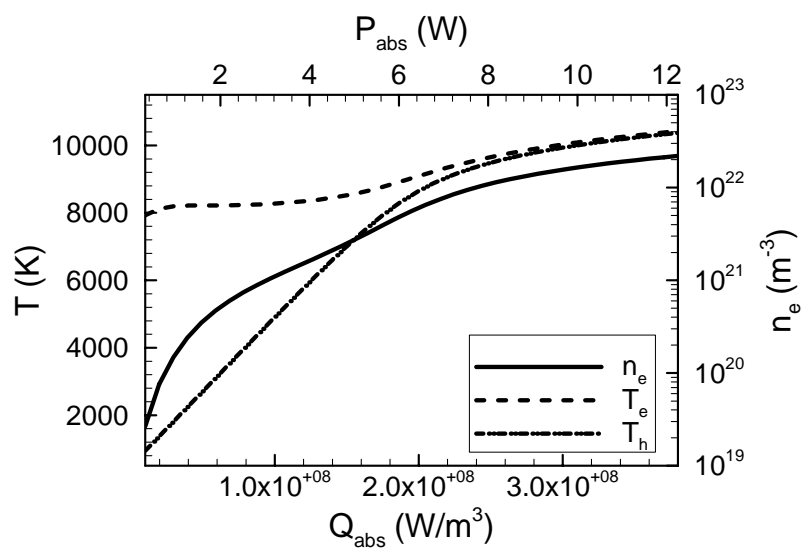

Fig.3 Plasma parameters (electron density $n_{\mathrm{e}}$, temperature $T_{\mathrm{e}}$, and heavy particle temperature $T_{\mathrm{h}}$ ) in microplasma source as a function of microwave power absorption density $Q_{\text {abs, }}$ calculated at atmospheric pressures $(0.1 \mathrm{MPa})$.

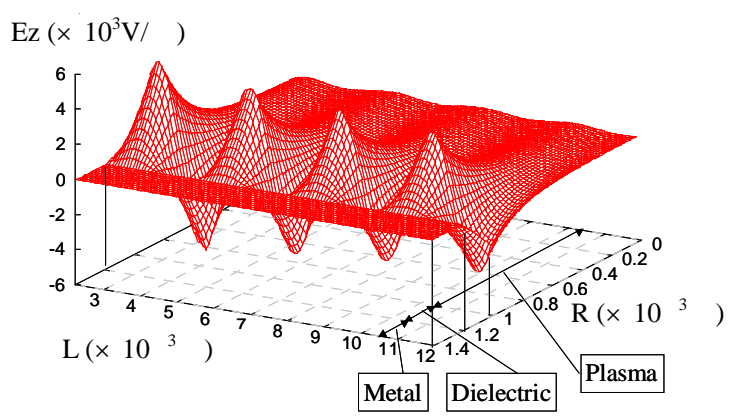

Fig.4 Snapshot of two-dimensional distribution of axial electric field component $E_{\mathrm{z}}$ of microwaves in microplasma source, calculated under conditions $f=24.5 \mathrm{GHz}, \varepsilon_{\mathrm{d}}=10, Q_{\mathrm{abs}}=2.0 \times 10^{7}$ $\mathrm{W} / \mathrm{m}^{3}\left(P_{\mathrm{abs}}=0.6 \mathrm{~W}\right)$, and pressure of $0.1 \mathrm{MPa}$. The surface waves are established in the microplasma chamber. 
存性は単調ではない)。

\section{2 マイクロノズル流れ}

Fig.6に , マイクロノズルの形状と計算格子を示す。ノズル の入口半径, スロート半径, 出口半径, 広がり角は, 弚れ光 れ $r_{\mathrm{in}}=0.3 \mathrm{~mm}, r_{\mathrm{t}}=0.1 \mathrm{~mm}, r_{\mathrm{ex}}=0.4 \mathrm{~mm}, \theta=20^{\circ}$ である。 ここで,軸方向の原点はプラズマ源とノズルの境界に取って いる。ノズル流れの計算では, 質量流量を $m=2.0 \mathrm{mg} / \mathrm{s}$ に固 定し,ノズル入口の境界条件にプラズマ源の解析結果を用い る。また , ノズル壁面において, 速度ゼロとする滑りなし条 件および輻射平衡条件 ${ }^{19)}$ を仮定した。

Fig.7(a), (b)に , プラズマ源の吸収電力密度が $Q_{\mathrm{abs}}=4.0$ $\times 10^{7}, 1.6 \times 10^{8} \mathrm{~W} / \mathrm{m}^{3}$ におけるノズル内のマッハ数の空間分 布を示す。図より，電力が大きくなるとマッ八数の最大值が ノズル内部に存在し,ノズル出口においてはむしろ速度が減 速されている樣子がわかる。これは，電力増加による重粒子 温度上昇の結果，境界層における粘性散逸が増大するためで ある。マイクロノズル流れでは，境界層の厚みとノズル断面 の特性長が同程度であり，マイクロプラズマ源と同樣，固体
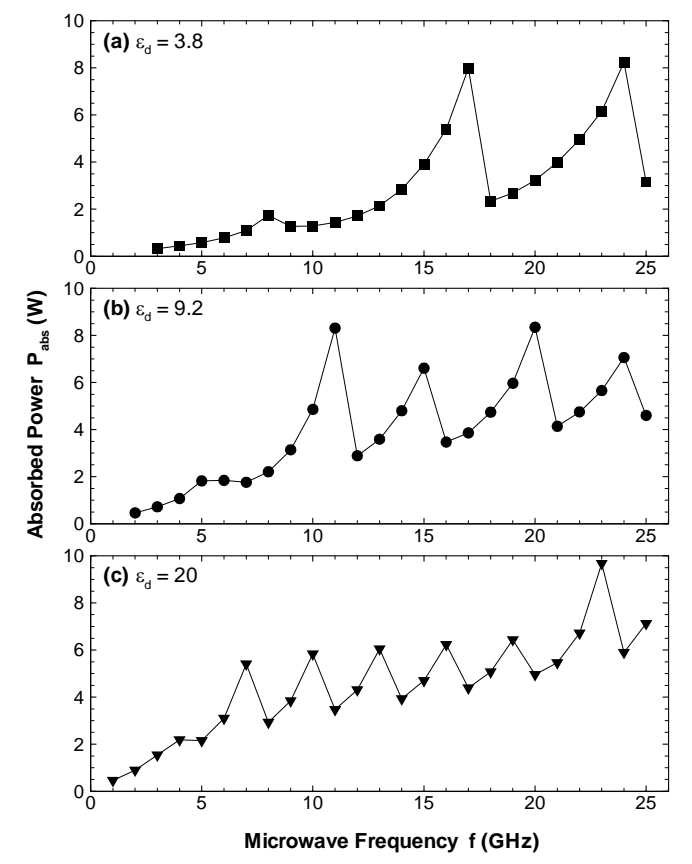

Fig.5 Absorbed power $P_{\text {abs }}$ of microwaves in microplasma source as a function of microwave frequency $f$, calculated for different relative permittivities $\varepsilon_{\mathrm{d}}$ at pressure of $0.1 \mathrm{MPa}$ with incident microwave power of $P_{\text {in }}=10 \mathrm{~W}$.

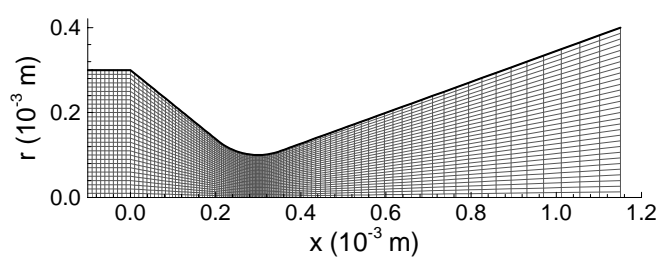

Fig.6 Cross section of micronozzle, and computational grids employed, where divergence angle is $\theta=20^{\circ}$.
表面でのプラズマやガスの振る舞い (ノズル壁面での流れ) の 理解と制御が重要となる。

次に,マイクロスラスターの推進性能解析のため，推進性 能の指標の一つである推力と比推力について議論する。真空 中における推力 $F_{\mathrm{t}}$ および比推力 $I_{\mathrm{sp}}$ は ,ノズル出口において 次式で定義される。

$F_{\mathrm{t}}=2 \pi \int_{0}^{r_{\mathrm{ex}}}\left(\rho u^{2}+p\right) r d r, \quad I_{\mathrm{sp}}=F_{\mathrm{t}} / n^{\infty} g$

ここで, $u$ は軸方向速度,$g$ は重力加速度， $n k$ は質量流量で あり, 推力は運動量推力と圧力推力からなる。また , 圧力推 力の寄与を調べるため, 圧力推力を含まない推力 $F_{\mathrm{t}}^{\prime}$ および 比推力 $I_{\mathrm{sp}}{ }^{\prime}$ を次式で定義する。

$F_{\mathrm{t}}{ }^{\prime}=2 \pi \int_{0}^{r_{\mathrm{ex}}} \rho u^{2} r d r, \quad I_{\mathrm{sp}}{ }^{\prime}=F_{\mathrm{t}}{ }^{\prime} / n k g$

Fig.8 に推力と比推力のプラズマ源の吸収電力密度 $Q_{\mathrm{abs}}$ に対 する依存性を示す。图より，吸収電力の増加とともにプラズ マ源の圧力・温度が上昇し, 弚の結果, 推力・比推力が増加 すること，また，一般には無視できる程小さい圧力推力の寄 与がマイクロノズルではかなりの割合を占め,電力の増加と ともに大きくなっていることがわかる。これは,ノズル内で, 粘性散逸による温度上昇に伴い圧力か増加し, 結果として圧 力推力の寄与が大きくなるためである。

さらに,ノズルの形状について検討する。Fig.9に Fig.6に 示したノズルに対して断面積比を一定にしたまま広がり角を $\theta=10^{\circ}$ および $30^{\circ}$ と変更した場合のノズル形状を示す。ま た Fig.10に , 吸収電力密度を $Q_{\text {abs }}=1.0 \times 10^{8} \mathrm{~W} / \mathrm{m}^{3}$ とした場 合の, 推力・比推力のノズル形状に対する依存性を示す。图 より，広がり角を大きくするに従い, 推力・比推力ともに増 加していることがわかる。特に運動量推力のみを考えた場合 の推力・比推力の増加か顕著であり，広がり角を大きくしノ ズルの全長を短くすることで,マイクロノズル内の境界層で の損失か軽減されるといえる。
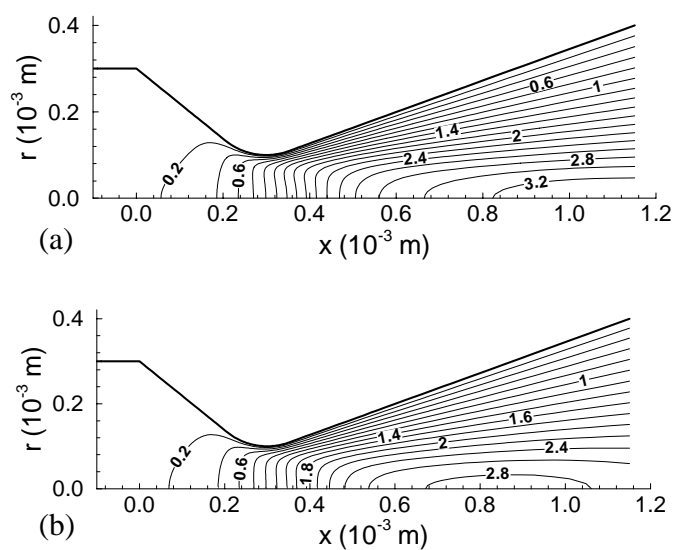

Fig.7 Mach number contours in micronozzle under radiative wall conditions, calculated for different microwave power absorption densities $Q_{\mathrm{abs}}=$ (a) $4.0 \times 10^{7}$ and (b) $1.6 \times 10^{8} \mathrm{~W} / \mathrm{m}^{3}$ at pressure of $0.1 \mathrm{MPa}$ in microplasma source and mass flow rate of $2.0 \mathrm{mg} / \mathrm{s}$. 


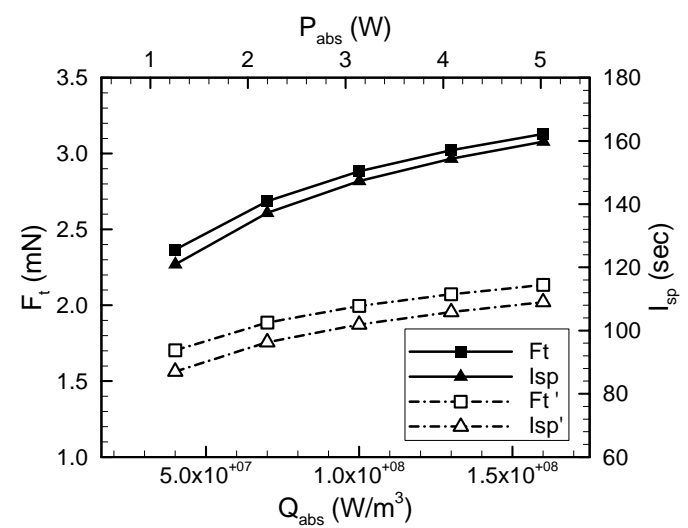

Fig.8 Thrust $F_{\mathrm{t}}$ and specific impulse $I_{\mathrm{sp}}$ as function of power absorption density $Q_{\text {abs }}$ (or power absorption $P_{\text {abs }}=Q_{\text {abs }} V$ ), calculated under same conditions of Fig.7. The $F_{\mathrm{t}}$ and $I_{\mathrm{sp}}$ consist of the two components originating from the momentum $\left(F_{\mathrm{t}}{ }^{\prime}, I_{\mathrm{sp}}{ }^{\prime}\right)$ and the pressure thrusts.

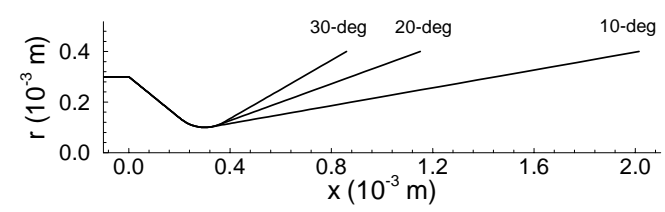

Fig.9 Cross section of three types of micronozzle, where divergence angles are $\theta=10^{\circ}, 20^{\circ}$, and $30^{\circ}$.

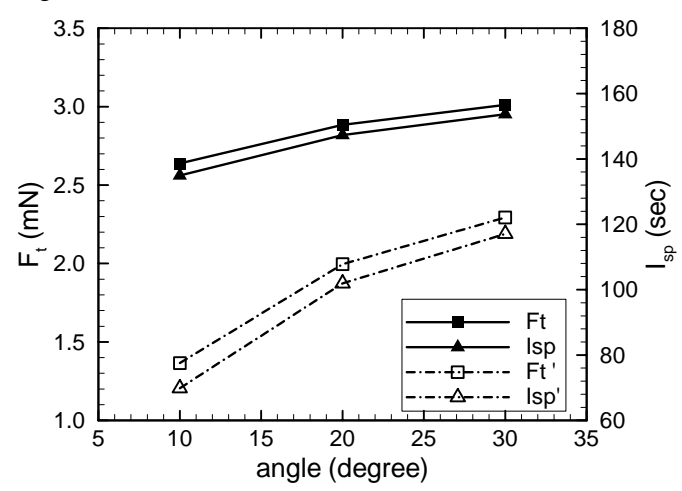

Fig.10 Thrust $F_{\mathrm{t}}$ and specific impulse $I_{\mathrm{sp}}$ for three different angles $\theta$ of micronozzle shown in Fig.9, calculated under the same conditions of Fig.7 with $Q_{\mathrm{abs}}=1.0 \times 10^{8} \mathrm{~W} / \mathrm{m}^{3}$. ( $F_{\mathrm{t}}{ }^{\prime}$ and $I_{\mathrm{sp}}$ ' are the same as in Fig.8.)

\section{4. 実験}

Fig.11に実験の概要を示す。実験装置は，マイクロ波供給 系, 推進剂 (ガス) 供給系，マイクロプラズマ源，および真 空排気系からなる。マイクロ波発振には信号発生器 (周波数 可変) を用い, 発振されたマイクロ波は, 半導体増幅器 (周 波数固定 ,4 個の高周波FET 素子から構成) により出力か約 1 万倍に増幅される。本実験では周波数が $f=2$ と $4 \mathrm{GHz}$ に 対応する 2 種類の増幅器を用意した。増幅されたマイクロ波 は,セミリジッドケーブルを介して石英管で作られたマイク ロプラズマ源へと供給され，プラズマが生成・維持される。 ここで,マイクロ波電力の整合はケーブルの長さを調整する

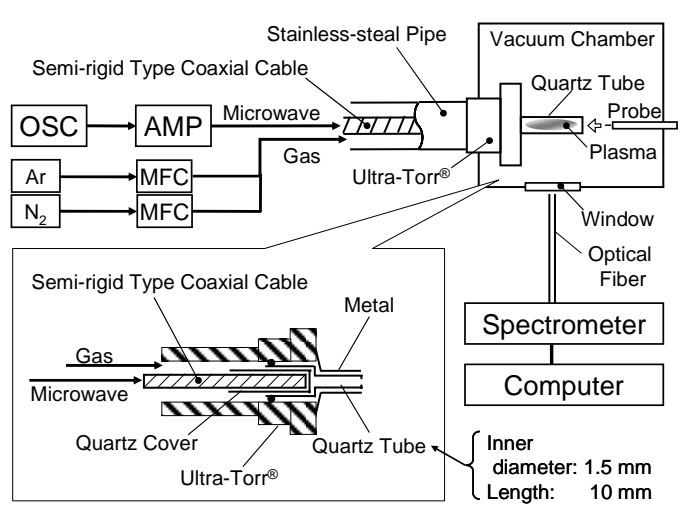

Fig.11 Schematic of experimental setup (top) and cross section of microplasma source developed (bottom).

ことで行う。また，プラズマ源にはSUS 管が接続され，推 進剤であるアルゴンガスおよび室素ガスが流量制御器を通し て供給される。なお，マイクロプラズマ源は, ドライポンプ により排気される真空容器内に設置され,プラズマ源の圧力 (投入ガス圧力) および容器圧力 (背圧) は, プラズマ源上流 部および真空容器に取り付けられた真空計によって測定され る。

Fig.12 にマイクロプラズマ源の構造を示す。マイクロ波供 給のためのセミリジッドケーブルは，外部導体と内部絶縁体 を先端から $10 \mathrm{~mm}$ 程度除去して内部導体を露出し, 該内部 導体をセラミックス管で覆い,さらに外部導体を石英管で覆 う。ここで, プラズマ生成における誘電体の比誘電率 $\epsilon_{\mathrm{d}}$ へ の依存性を調べるため, ムライト $\left(3 \mathrm{Al}_{2} \mathrm{O}_{3} \cdot 2 \mathrm{SiO}_{2}, \epsilon_{\mathrm{d}}=6\right)$ と ジルコニア $\left(\mathrm{ZrO}_{2}, \epsilon_{\mathrm{d}}=12 \sim 25\right)$ の2 種類のセラミックス管を 用意した。このセラミックス管で覆われたケーブル先端を， 内径 $1.5 \mathrm{~mm}$, 長さ $10 \mathrm{~mm}$ の石英管 (プラズマ容器) に挿入 する。現段階ではマイクロノズルは装着しておらず，石英管 の先端は内径 $0.4 \mathrm{~mm}$ のオリフィス状に加工してある。さら に,マイクロ波電磁界を閉じ込めるため, 石英管は接地した 金属導体で覆われる。なお，金属導体は，プラズマ観測用に スリットを有するが,スリットがスロットアンテナにならな いよう，さらに金属メッシュで覆われている。

プラズマからの発光スペクトルは, 真空容器の側壁空に取 り付けられた光ファイバを介して, 分光器 (焦点距離 $10 \mathrm{~cm}$ ) を用いて測定される。なおここで,レンズによる集光は行っ ていない。また, 静電プローブをプラズマ容器のオリフィス 下流に設置して, プラズマ密度を測定する。プローブは, 半 径 $0.025 \mathrm{~mm}$ のタングステン線を絶縁管から $0.5 \mathrm{~mm}$ だけむき 出しにした円筒型シングルプローブである。

\section{5. 実験結果と考察}

\section{1 発光強度のマイクロ波電力依存}

Fig.13に プラズマの発光スペクトル強度 [Ar I (763.5 nm)] およびマイクロ波反射係数 $C_{\mathrm{rf}}$ とマイクロ波投入電力 $P_{\mathrm{t}}$ との 関係を示す。実験条件は, マイクロ波周波数 $f=4 \mathrm{GHz}$, セ 


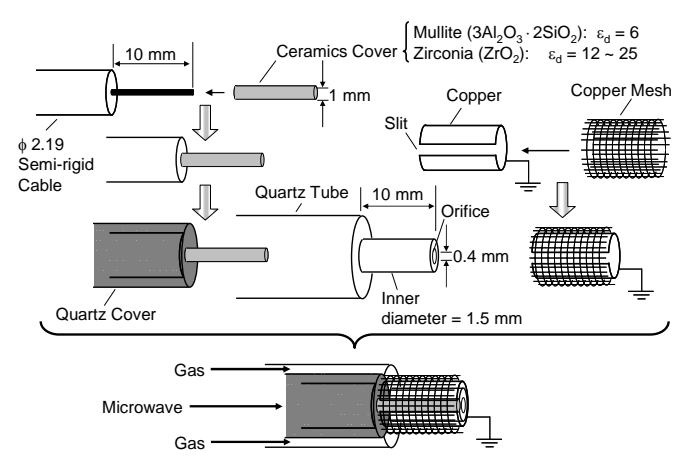

Fig.12 Assembly of microplasma source presently developed, which has orifice at exit to vacuum. The slit of the copper envelope is for optical diagnostics.

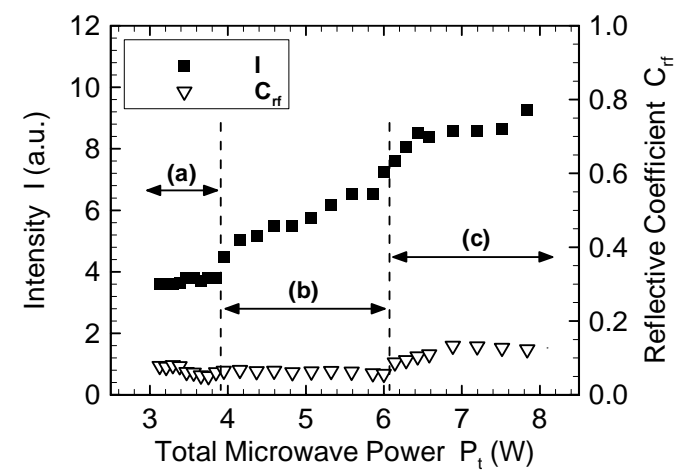

Fig.13 Emission intensity (Ar I $763.5 \mathrm{~nm}$ ) and microwave reflective coefficients $C_{\mathrm{rf}}=P_{\mathrm{rf}} / P_{\mathrm{t}}$ as a function of total microwave power $P_{\mathrm{t}}$ ( $f=4 \mathrm{GHz})$ with mullite tube $\left(\varepsilon_{\mathrm{d}}=6\right)$, measured at Ar flow rate of $50 \mathrm{sccm}$, plasma chamber pressure of $10 \mathrm{kPa}$, and vacuum chamber pressure of $9 \mathrm{~Pa}$.

ラミックス管の比誘電率 $\epsilon_{\mathrm{d}}=6$,アルゴンガス流量 $50 \mathrm{sccm}$, 投入ガス圧力 $10 \mathrm{kPa}$, 背圧 $9 \mathrm{~Pa}$ である。反射係数 $C_{\mathrm{rf}}=P_{\mathrm{rr}} / P_{\mathrm{t}}$ は，マイクロ波反射電力 $P_{\mathrm{rf}}$ を投入電力 $P \mathrm{t}$ で除することに より算出した。図より，投入電力 $P_{\mathrm{t}}$ の増加とともに発光強 度と反射係数が増加していることがわかる。発光強度と反射 係数の変化の樣子は, 3 つの領域 (a)-(c)に大別され，投入電 力 $P_{\mathrm{t}}$ を変化させることでプラズマの生成・維持の樣子が変 化していることを示唆する。Fig.14(a)-14(c) に対応するプラ ズマ生成の樣子を示す。(a)ではプラズマ容器 (石英管) 内部 のみでプラズマが生成・維持され，(b) ではプラズマが自由 噴流 (フリージェット) として真空容器内に噴出している。 (c) では噴出したプラズマが，さらにプラズマ源の周りに広 がっている樣子がわかる。なお，この自由噴流が超音速自由 噴流であることは，自由噴流の軸上にマッハ円板 (Mach disk)， また周囲に樽型衝撃波 (barrel shock) ,の 2 種類の衝撃波構造 が観測されることから明らかである。

\section{2 発光強度の周波数依存}

Fig.15に発光スペクトル強度のマイクロ波周波数依存性 を示す。マイクロ波周波数は $f=2$ および $4 \mathrm{GHz}$ であり，光

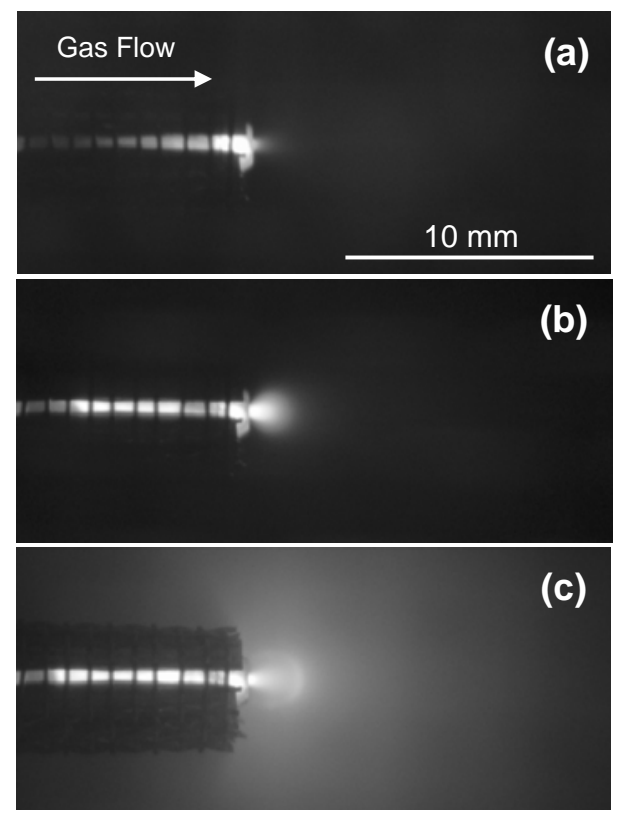

Fig.14 Photograph images of emission of microplasma discharges, taken for $P_{\mathrm{t}}=$ (a) 3, (b) 5, and (c) $8 \mathrm{~W}$ under the same conditions as in Fig.13.

の他の実験条件は Fig.13 と同じである。また，図の横軸は マイクロ波入射電力 $P_{\text {in }}=P_{\mathrm{t}}-P_{\mathrm{rf}}$ であり,マイクロ波投入電力 $P_{\mathrm{t}}$ から反射電力 $P_{\mathrm{rf}}$ を差し引き,プラズマ源に投入された正 味のマイクロ波電力とみなすことができる。図において , 周 波数 $f=2 \mathrm{GHz}$ の場合も $f=4 \mathrm{GHz}$ と同樣, 電力の増加とと もに発光強度力増加し，変化の樣子は 3 つの領域に大別され る。しかし, 発光強度の急激な変化か現れる入射電力 $P_{\text {in }}$ の 値は $f=4 \mathrm{GHz}$ の方が $f=2 \mathrm{GHz}$ よりも小さく $f=4 \mathrm{GHz} の$ 方が同じ電力下での発光強度は強い。すなわち, 高いマイク 口波周波数においてプラズマ生成が効率的なことがわかる。

\section{3 発光強度の比誘電率依存}

Fig.16に発光スペクトル強度の比誘電率依存性を示す。 セラミックス管の比誘電率は $\epsilon_{\mathrm{d}}=6$ および 12〜25 であり， 产の他の実験条件は Fig.13 と同じである。図の横軸はマイ クロ波入射電力 $P_{\text {in }}$ である。この图からも，電力の増加にと もなう発光強度の増加,および変化の 3 つの領域が確認でき る。また，高い比誘電率 $\epsilon_{\mathrm{d}}=12 \sim 25$ の方が，発光強度の急 激な変化か現れる入射電力 $P_{\mathrm{in}}$ の値は小さく，同じ電力下で の発光強度は強い。すなわち, 高い比誘電率においてプラズ マ生成か効率的なことがわかる。

\section{4 電子密度}

Fig.17に静電プローブを用いた電子密度 $n_{\mathrm{e}}$ の測定結果を 示す。マイクロ波周波数は $f=2$ および $4 \mathrm{GHz}$, セラッミク ス管の比誘電率は $\epsilon_{\mathrm{d}}=6$ および $12 \sim 25$ であり，光の他の 実験条件は Fig.13 と同じである。プローブは，Fig.11 のよ うに ,プラズマ容器のオリフィス下流に ,プラズマ自由噴流 


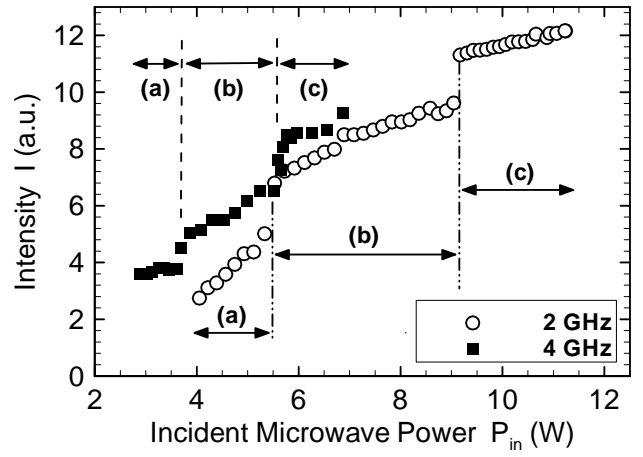

Fig.15 Emission intensity (Ar I $763.5 \mathrm{~nm}$ ) as a function of incident microwave power $P_{\text {in }}=P_{\mathrm{t}}-P_{\mathrm{rf}}$ for different microwave frequencies $f=2$ and $4 \mathrm{GHz}$, otherwise measured under the same conditions as in Fig.13.

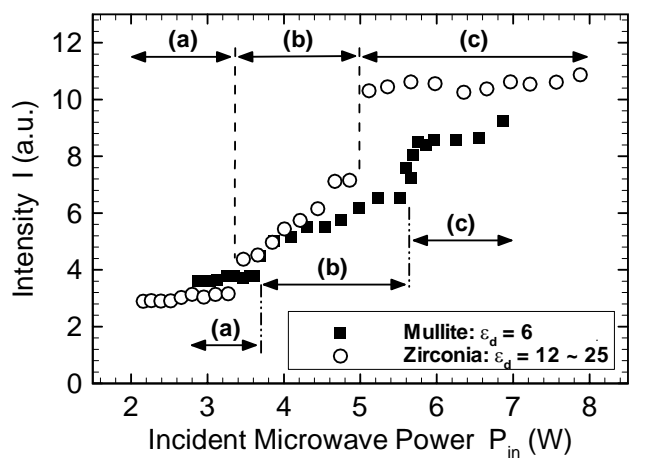

Fig.16 Emission intensity (Ar I $763.5 \mathrm{~nm}$ ) as function of incident microwave power $P_{\text {in }}=P_{\mathrm{t}}-P_{\mathrm{rf}}$ for different ceramic tubes of $\varepsilon_{\mathrm{d}}=$ 6 and 12-25, otherwise measured under the same conditions as in Fig.13.

に平行に設置した。高い入射電力 $P_{\mathrm{in}}>5 \mathrm{~W}$ では, 高い周波 数·比誘電率ほど電子密度が大きく これまでのFig.15, Fig.16 の結果と矛盾しない。測定された電子密度は, $P_{\mathrm{in}}=10 \mathrm{~W} に$ おいて $n_{\mathrm{e}} \approx 5 \times 10^{12} \mathrm{~cm}^{-3}$ 程度であるが , プラズマの超音速自 由噴流の理論や実験からは,プラズマ源内の密度は 1 椼以上 高いものと推測される。

低い入射電力 $P_{\mathrm{in}}<5 \mathrm{~W}$ においては,$f=2 \mathrm{GHz}$ における電 子密度が $f=4 \mathrm{GHz}$ より高い。これは, $f=2 \mathrm{GHz}$ の場合，プ ローブをプラズマ源，すなわちオリフィスに近づけると，プ ラズマへの擾乱が大きく,プラズマがプローブの周り全体に 広がるためであり，プラズマの生成・維持機構か変化するこ とに関連すると推測される。 $f=4 \mathrm{GHz}$ では, プローブ設置 によるプラズマの擾乱は認められなかった。

\section{5 回転温度}

少量の窒素を添加して, 窒素分子発光スペクトルの振動回 転バンドを解析し, 回転温度からガス温度を見積もった。実 験では, $\mathrm{N}_{2} 2+(0,0)$ band $(337.1 \mathrm{~nm})$ を観測し, 振動回転スペ クトルを, 理論スペクトルと比較して回転温度 $T_{\mathrm{rot}}$ を算出し た。Fig.18(a)に, 回転温度および発光スペクトル強度 $[\mathrm{ArI}$

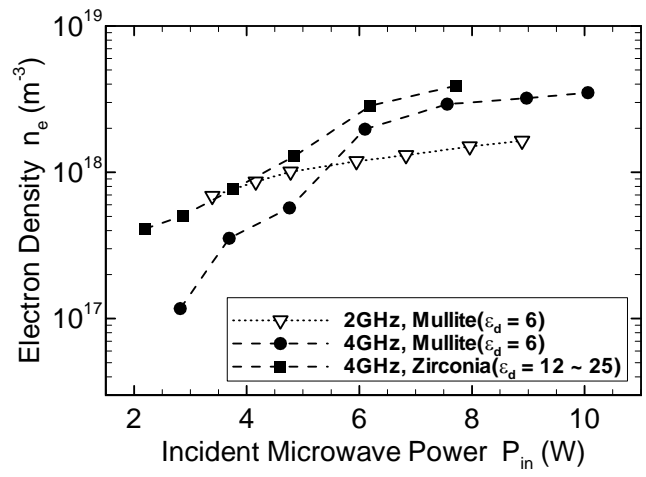

Fig.17 Electron density $n_{\mathrm{e}}$ as a function of incident microwave power $P_{\text {in }}$ $=P_{\mathrm{t}}-P_{\mathrm{rf}}$ for different $f=2$ and $4 \mathrm{GHz}$ and different $\varepsilon_{\mathrm{d}}=6$ and 12-25, otherwise measured under the same conditions as in Fig.13. Here, the Langmuir probe was located at downstream from the orifice as in Fig.11; thus, the $n_{\mathrm{e}}$ may be larger about an order of magnitude in the microplasma chamber.

$(763.5 \mathrm{~nm})$ ) と，マイクロ波投入電力 $P_{\mathrm{t}}$ との関係を示す。 ここで, マイクロ波周波数は $f=4 \mathrm{GHz}$, セラッミクス管の 比誘電率は $\epsilon_{\mathrm{d}}=12 \sim 25\left(\mathrm{ZrO}_{2}\right)$, 混合ガスは $\mathrm{Ar} 50 \mathrm{sccm} / \mathrm{N}_{2} 1$ $\mathrm{sccm}$, 光の他の実験条件は Fig.13 と同じである。測定され た回転温度は,$P_{\mathrm{t}}=10 \mathrm{~W}$ において $T_{\mathrm{rot}} \approx 1500 \mathrm{~K}$ 程度である。 図において, 電力の増加とともに発光強度力増加し, 乥れに 伴い回転温度も増加することがわかる。しかし, 室素分子の 解離や振動励起等に電子のエネルギーが使われるため,アル ゴンのみの場合と比較して，同じ投入電力 $P_{\mathrm{t}}$ における発光 強度は弱い。また, 電力の増加にともなう発光強度や回転温 度の急峻な変化が観測されるが,アルゴンのみの場合と比較 して变化は緩やかである。

\section{6 比推力}

Fig.18(b)に，回転温度をガス温度とみなし，2 節, 3 節のモデ ル解析から，スラスターとしての比推力 $I_{\mathrm{sp}}$ を見積もった結 果を示す。ここで, ノズルの形状は, モデル解析のスロート 径を $0.2 \mathrm{~mm}$ から実験で用いたオリフィス径 $0.4 \mathrm{~mm}$ 一拡大 したものである。なお，ノズル入口の境界条件は実験条件と 同じとした。图において，マイクロ波投入電力 $P_{\mathrm{t}}=10 \mathrm{~W}$ で 比推力 $I_{\mathrm{sp}} \approx 70 \mathrm{~s}$ 程度であり, 温度の上昇とともに比推力が 上昇する。同じ条件下でのコールドガススラスターの比推力 は $I_{\mathrm{sp}, \text { cold }} \approx 54 \mathrm{~s}$ 程度であり, 比推力の増加率は $\left(I_{\mathrm{sp}} I_{\mathrm{sp}, \mathrm{cold}}\right) / I_{\mathrm{sp}, \text { cold }} \approx 30 \%$ 程度 , マイクロ波投入電力 $P_{\mathrm{t}}$ の範囲で 推進効率は $\approx 0.2 \sim 1.2 \%$ となる。この低い推進性能は, プ ラズマ源のガス温度および圧力が低いことに起因する。2 節, 3 節に示したように, ノズル入口での圧力が低いと低レイノ ルズ数流れとなり，ノズル内部全体が境界層で覆われて速度 損失の影響が大きい。推進性能向上には,プラズマ源のガス 温度および圧力を上昇させることが課題となる。 


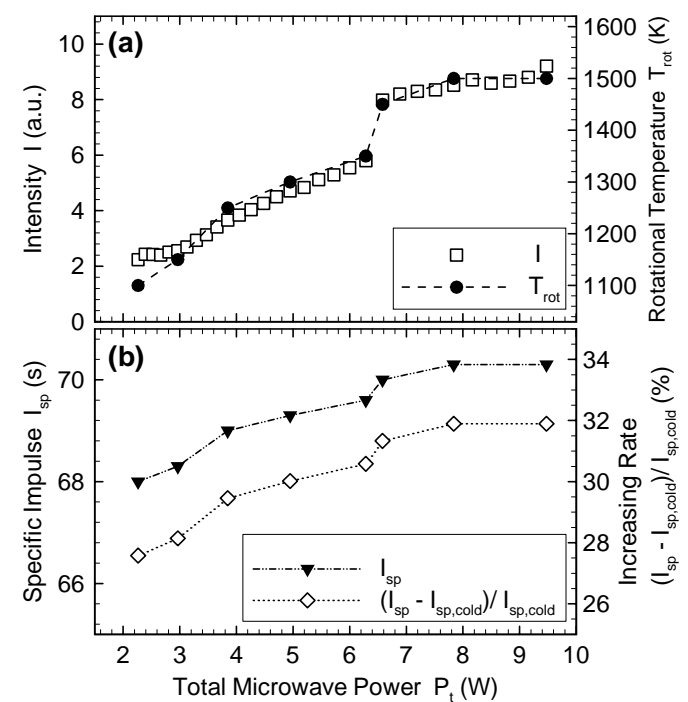

Fig.18 (a) Rotational temperature $T_{\text {rot }}\left(\mathrm{N}_{2}\right)$ and emission intensity (Ar I $763.5 \mathrm{~nm})$ as a function of total microwave power $P_{\mathrm{t}}$ for $f=4$ $\mathrm{GHz}, \varepsilon_{\mathrm{d}}=12-25$, and Ar-50/ $\mathrm{N}_{2}-1 \mathrm{sccm}$, otherwise measured under the same conditions as in Fig.13. (b) Specific impulse $I_{\mathrm{sp}}$ as a function of $P_{\mathrm{t}}$, estimated from the measured temperature $T=$ $T_{\text {rot }}$ and the model analysis of Figs.6-8. Also shown is the specific impulse $I_{\mathrm{sp}, \text { cold }}$ for the cold gas thruster, estimated using the present model analysis.

\section{6. 結言}

マイクロ波励起マイクロプラズマスラスターについて , マ イクロプラズマ源 (内径 $2 \mathrm{~mm}$, 長さ $10 \mathrm{~mm}$ ) におけるプラ ズマの生成・維持, およびマイクロノズル (スロート径 0.2 mm) におけるプラズマ流れについて , 作動ガスをアルゴン としてモデル数值解析を行った。具体的には,軸対称表面波 励起マイクロプラズマについて、プラズマに関するグローバ ルモデルと, マイクロ波電磁界に関する 2 次元 FDTD 法を 適用した。さらに、マイクロノズル流れについて , 2 温度モ デルに基づくナビエ・ストークス方程式を解き、推進性能の 評価を行った。解析の結果，(1)マイクロ波周波数と誘電体 比誘電率が高いほどプラズマ生成か効率的 (大気圧下でプラ ズマ密度 $10^{14}-10^{16} \mathrm{~cm}^{-3}$ ), (2)マイクロノズルでは境界層がノ ズル断面の特性長と同程度となり境界層構造の理解と制御が 重要 (ノズル広がり部で減速)，(3)マイクロ波電力 < $10 \mathrm{~W}$ に おいて推力 2.5-3.5 mN , 比推力 130-180 s 程度, であること がわかった。この推進性能からは, 本マイクロプラズマスラ スターが, 小型衛星 $(<10 \mathrm{~kg})$ の軌道・姿勢制御に適用でき ることが期待できる。

さらに,マイクロプラズマ源 (内径 $1.5 \mathrm{~mm}$, 長さ $10 \mathrm{~mm}$, 同軸型) を試作し，アルゴンガスを用いて微小領域でのマイ クロ波励起マイクロプラズマの生成・維持, および微小オリ フィス (オリフィス径 $0.4 \mathrm{~mm}$ ) を通しての真空中へのプラ ズマの超音速自由膨張を実証するとともに，発光分光と静電 プローブ計測によりプラズマ特性を把握し，モデル解析に基
づき推進特性を推算した。マイクロ波は周波数が 2 と $4 \mathrm{GHz}$ $(<10 \mathrm{~W})$, 誘電体は比誘電率が 6 と 12-25 を用いた。実験の 結果, (i)マイクロ波周波数と誘電体比誘電率が高いほど発光 強度は強くプラズマ密度は高い, (ii)マイクロ波投入電力 2-10 W において , オリフィス下流のプラズマ自由噴流における プラズマ密度は $10^{11}-10^{13} \mathrm{~cm}^{-3}$ 程度 (プラズマ源では 1 桁程 度高いと推測),(iii)窒素添加により見積もった窒素分子の回 転温度は 1100-1500 K 程度，であることがわかった。回転温 度をガス温度とみなして，モデル解析結果にもとづくと，期 待できる比推力は $70 \mathrm{~s}$ 程度であった。実験值はいずれもモ デル解析值と比較してやや劣り, 差異の要因は今後究明して いく。

今後, 詳細なプラズマ計測・診断により，微小閉鎖領域の マイクロ波励起プラズマ,およびマイクロノズル流れの特徵 を明らかにする。また，マイクロノズルを MEMS 技術によ り製作するとともに ,マイクロプラズマスラスター全体の構 造の最適化と精密加工による製作をはかる。さらに，微小推 力測定のための機器を考案・作製し , スラスターとしての推 進性能を実測する。

\section{引用 文 献}

1) H. Helvajian and S.W. Janson: "Microengineering Aerospace Systems”, ed. by H. Helvajian, AIAA, 1999, Chap. 2.

2) J. Mueller: "Micropropulsion for Small Spacecraft", ed. by M.M. Micci and A.D. Ketsdever, AIAA, 2000, Chap. 3.

3) K. Terashima, L. Howald, H. Haefke and H. Guntherodt: Thin Solid Films 281-282 (1996) 634-636.

4) H. Yoshiki and Y. Horiike: Jpn. J. Appl. Phys. 40 (2001) 360-362.

5) J. Hopwood, O. Minayeva and Y. Yin: J. Vac. Sci. Technol. B 18 (2000) 2446-2451.

6) A.M. Bilgic, U. Engel, E. Voges, M. Kuckelheim and J.A.C. Broekaert: Plasma Sources Sci. Technol. 9 (2000) 1-4.

7) Y. Takao and K. Ono: AIAA Paper 2004-3621, AIAA, 2004.

8) Y. Takao and K. Ono: ISTS Paper 2004-o-1-08v, JSAAS, 2004.

9) Y. Takao, K. Ono, K. Takahashi and Y. Setsuhara: Bull. Am. Phys. Soc. 49 (2004) 40.

10) Y. Takao, K. Ono, K. Takahashi and Y. Setsuhara: to be published in Thin Solid Films (2005).

11) Y. Takao and K. Ono: submitted to Plasma Sources Sci. Technol.

12) M.A. Lieberman and A.J. Lichtenberg: "Principles of Plasma Discharges and Materials Processing”, Wiley, 1994.

13) H. Kousaka and K. Ono: Jpn. J. Appl. Phys. 41 (2002) 219-2206.

14) H. Kousaka and K. Ono: Plasma Sources Sci. Technol. 12 (2003) 273-286.

15) M. Mitchner and C. H. Kruger, Jr.: "Partilally Ionized Gases”, Wiley, 1973.

16) Y. Bartosiewicz, P. Proulx and Y. Mercadier: J. Phys. D 35 (2002) 2139-2148.

17) K.S. Yee: IEEE Trans. Antennas Propagat. 14 (1966) 302-307.

18) J.D. Anderson, Jr.: "Computational Fluid Dynamics: The Basics with Applications”, McGraw-Hill, 1995.

19) S. Kuchi-ishi and M. Nishida: IEPC Paper 1999-029. AIAA, 1999. 